\title{
The Recording Angel
}

Music, Records and Culture from Aristotle to Zappa Second Edition

\author{
Evan Eisenberg
}


This Second Edition published in 2005 by Yale University Press First published in the United States of America in 1987 by McGraw-Hill Copyright $(\mathcal{C} 1987,2005$ by Evan Eisenberg

All rights reserved.

This book may not be reproduced, in whole or in part, including illustrations, in any form (beyond that copying permitted by Sections 107 and 108 of the U.S. Copyright Law and except by reviewers for the public press), without written permission from the publishers.

Printed in the United States of America

Library of Congress Control Number: 2004117200

ISBN 978-0-300-09904-1

A catalogue record for this book is available from the British Library.

The paper in this book meets the guidelines for permanence and durability of the Committee on Production Guidelines for Book Longevity of the Council on Library Resources.

10987654 
For my father, my mother, and my wife 
The author and publishers would like to thank the following for permission to use copyrighted material in this book.

Excerpt from Theoguny, Works and Days, Elegirs, by Hesiod and Theognis, translated with an introduction by Dorothea Wender (Penguin Classics, 1973). Copyright (을 Dorothea Wender, 1973. Reproduced by permission of Penguin Books Led.

"Life During Wartime," by David Byrne, Jerry Harrison, Chris Frantz and Tina Weymouth.

Copyright ( 1979 WB Music Corp. (ASCAP) and Index Music, Inc. (ASCAP). All rights administered by WB Music Corp. All rights reserved. Used by pernission of Warner Bros. Publications U.S. Inc., Miami, FL 33014.

"One Nation Under A Groove," written by George Clinton, Jr./Garry M. Shider/ Walter Morrison. Copyright ( 1979 by Bridgeport Music hnc, (BMJ). Used by pernission.

"P Funk (Wants To Get Funked Up." written by George Clinton, Jr./Bernard G. Worrell/William Earl Collins. Copyright $(1976$ by Bridgeport Music Inc. (BMI). Used by permission.

"Groovallegiance," written by George Clinton, Jr./Walter Morrison/Bernard G. Worrell. Copyright (c) 1979 by Bridgeport Music inc. (BMI). Used by permission.

"Give Up the Funk (Tear the Roof Off the Sucker)," written by George Clinton, Jr./William Earl Collins/Jerome Brailey. Copyright $(1) 1976$ by Bridgeport Music Inc. (BMI). Used by permission.

"Unfunky UFO," written by George Clinton, Jt./Garry M. Shider/Willian Earl Collins. Copyright (c) 1976 by Bridgeport Music Inc. (BMI). Used by pernission.

"I Got A Thing, You Got A Thing, Everbody's Got A Thing," written by Clarence Haskins.

Copyright $(1971$ by Bridgeport Music Inc. (BMI). Used by permission.

"Who Says A Funk Band Can't Play Rack?" Written by George Clinton, Jr. Walter Junie Morrison' Michael Hampton. Copyright (C) 1978 by Bridgeport Music ltc. (BMI). Used by permission.

Quote from "School Days" copyright (C) 1957 used by permission of Isalee Music Co. (BMI). All rights for the world excluding the United States controlled by Arc Music Corp. (BMI). "Hail, Hail Rock and Rol!!" is a registered trademark of Mr. Chuck Berry.

"Waik on the Wild Side." Words and music by Lou Reed copyright $(1972$ (renewed 2000) Oakfield Avenue Music Ltd. All rights controlled and administered by Screen Gems-EMI Music Inc. Ail rights reserved. International copyright secured. Used by permission.

"Tupelo Honey," by Van Morrison, Copyright (1) 1971 (renewed) WB Music Corp. and Caledonia Soul Music. All rights on behalf of Caledonia Soul Music adninistered by WB Music Corp. All rights reserved. Used by permission of Warner Bros. Publications U.S. Inc., Miami, FL 33014.

Excerpe from "Down at the Docks," by Kenneth Koch, reproduced by permission of Kenneth Koch Literary Escate.

Portions of Chapter Seven appeared in different form in The Nation. 